\title{
PEMEROLEHAN FONOLOGI ANAK USIA 6 TAHUN DENGAN RIWAYAT KEJANG DEMAM \\ (Studi kualitatif pemerolehan fonologi pada Nazwa)
}

\author{
Happy Sri Rezeki Purba, M.Hum \\ Prodi Pendidikan Bahasa Inggris \\ Fakulatas Ilmu Pendidikan dan Keguruan \\ Universitas Muhammadiyah Tapanuli Selatan
}

\begin{abstract}
Penelitian ini bertujuan untuk mengetahui pemerolehan fonologi anak usia 6 tahunu dengan riwayat kejang demam melalui studi kualitatif. Peneliti mengumpul data dari percakapannya dengan Subjek penelitian (Nazwa) yang berlangsung selama kurang lebih enam bulan. Dalam penelitian ini didapatkan dua hasil penelitian yaitu: Pertama, Nazwa memperoleh 6 fonem vokal dan 18 fonem consonant, Kedua, Nazwa mengalami kesulitan dalam pemerolehan fonem konsonan velar [k,g] dan nasal [n]. Penelitian ini diharapkan dapat menambah khasanah ilmu pengetahuan khususnya dalam bidang psikolinguistik dan memberikan informasi bagi siapa saja yang tertarik dengan pemerolehan fonologi.
\end{abstract}

Kata Kunci: Pemerolehan Fonologi, Kejang Demam

\section{PENDAHULUAN}

Kemampuan memperoleh bahasa merupakan salah satu tanda perkembangan normal bagi seorang anak. Chomsky yang kutip oleh Subyakto-Nababan mengatakan bahwa setiap manusia mernpunyai apa yang dinamakan falcuties of the mind, yakni semacam kapling-kapling intelektual dalam benak atau otak mereka dan salah satunya dijatahkan untuk pemakaian dan pemerolehan bahasa. Seorang yang normal akan memperoleh bahasa ibu dalam waktu singkat. Hai ini bukan karena anak memperoleh rangsangan saja, lalu si anak mengadakan respon, tetapi karena setiap

ISSN 2541-3775 anak yang iahir telah dilengkapi dengan seperangkat peralatan yang memperoleh bahasa ibu. Alat ini disebut dengan Language Acquisition Device (LAD) atau lebih dikenal dengan nama piranti pemerolehan bahasa.

Piranti pemerolahan bahasa berkaitan langsung dengan usia dan faktor kesehatan serta perkembangan anak. Anak dengan perkembangan dan kesehatan yang baik tentu mampu memperoleh bahasa dengan baik pula sebab tidak terjadi gangguan pada piranti pemerolehan bahasa mereka. Namun, bagi anak dengan proses perkembangan dan kesehatan yang kurang Vol.3 No.1 Januari - Juni 2018/ 15 
baik seperti terserang kejang demam (step) cenderng akan mengalami gangguan fungsi dari piranti ini dan menghambat mereka untuk memperoleh bahasa khususnya dalam pelafalan kata atau produksi bunyi.

Anak-anak yang pernah mengalami serangan kejang saat demam (step) cenderung mengalami gangguan dalam proses pemerolehan bahasa. Kejang demam adalah serangan kejang yang terjadi karena kenaikan suhu tubuh (suhu rektal di atas 38) (Sujono Riyadi, 2013). WHO memperkiraan pada tahun 2005 terdapat 21,65 juta penderita kejang demam dan lebih dari 216 ribu diantaranya meninggal.

Di Indonesia sendiri, kejang demam dapat menyerang anak dari usia 6 bulan hingga 5 tahun. Usia ini merupakan usia keemasan dari perkembangan seorang anak baik perkembangan kognitif maupun psikomotorik dan linguistic. Perkembangan ini juga sejalan dengan tahap-tahap pemerolehan bahasa anak.

Pemerolehan bahasa meliputi pemerolehan sintaksis, semantik, dan fonologi. Komponen-komponen bahasa tersebut diperoleh atau berkembang secara bersama. Namun dalam pengkajiannya komponen-komponen linguistik tersebut dilakukan secara terpisah. Dalam kesempatan ini penulis mengadakan penelitian kecil tentang pemerolehan fonologi pada seorang anak dengan riwayat kesehatan mengalami kejang demam lebih dari 5 kali dan melalui penelitian ini juga dipaparkan kesalahan-kesalahan fonologi yang terjadi selama proses pemerolehan fonologi anak.

\section{PEMEROLEHAN FONOLOGI}

Dalam ilmu linguistik fonologi sebagai salah satu aspek yang terdapat di dalamnya yang mempelajari tentang fonem serta bunyi-bunyi yang diucapkan anak sejak umur satu tahun yang akan dilihat sebagai bagian dari pemerolehan bahasa. Menurut Ingram (1987; h.420) dalam pemerolehan fonologi setiap individu mempunyai variasi, yaitu: 1) variasi performance yang timbul berdasarkan keturunan dalam bentuk pilihan yang berbeda atau kemampuan perbedaan tipe belajar sehingga menentukan perbedaan diantara anak, 2) variasi lingkungan yang disebabkan oleh perbedaan dalam input pada anak yang berbeda, 3) variasi linguistik yang timbul dari sejumlah pilihan yang berbeda pada peranti pemerolehan bahasa yang menyediakan pemerolehan terutama jenis struktur. Dengan demikian jenis variasi individu dalam pemerolehan fonologi 
dipengaruhi berdasarkan ketiga variasi tersebut.

Perkembangan sistem fonologi anakanak dimulai jika anak-anak dapat mengucapkan kata pertama dalam bahasa yang benar yaitu untuk menyampaikan arti. Dengan demikian pemerolehan sistem bunyi yang sebenarnya dimulai pada saat anakanak mengucapkan kata pertama untuk tujuan komunikasi ketika anak - anak berusia kurang lebih 1 tahun.

Jacobson dalam Dardjowidjojo (2000; h.21) mengatakan bahwa adanya keuniversalan dalam bunyi-bunyi bahasa itu sendiri diperoleh secara berurutan dalam pemerolehannya. Anak memperoleh bunyibunyi itu melalui suatu cara yang konsisten dan pemerolehan bunyi pun berjalan serasi dengan kodrat bunyi itu sendiri. Langkah awal yang dikeluarkan oleh anak adalah lawan kata antara konsonan dan vokal. Ada tiga vokal yang sifatnya universal artinya, ketiga bunyi vokal tersebut terdapat dalam bahasa manapun yaitu vokal [a,i,u]. Pada kenyataannya ada juga bahasa yang memiliki lebih dari tiga vokal tetapi tidak ada bahasa yang memiliki kurang dari tiga vokal tersebut. Bahasa Indonesia termasuk bahasa yang memiliki lebih dari tiga vokal yaitu [a i u o $\varepsilon$ c $\partial$.
Menurut Jacobson bahwa inventori bunyi-bunyi dapat saja dibedakan dengan bahasa satu dengan bahasa lainnya tetapi berhubungan sesama bunyi itu sendiri mempunyai sifat universal. Hukum solidaritas Tak-terbalikkan Laws if Irreversible Solidarity yaitu:

1. Jika suatu bahasa mempunyai konsonan hambat velar (velar stops), maka bahasa tersebut tentu mempunyai konsonan hambat dental dan bilabial. Contoh: jika bahasa X mempunyai $[\mathrm{k}]-[\mathrm{g}]$, bahasa ini pasti mempunyai [t] -[d] dan [p]-[b].

2. Jika suatu bahasa mempunyai konsonan frikatif, bahasa tersebut pasti mempunyai konsonan hambat, Contoh: Jika bahasa $\mathrm{X}$ mempunyai $[\mathrm{f}]-[\mathrm{v}]$, bahasa ini pun pasti mempunyai [p-b], [t-d], [k-g].

3. Jika suatu bahasa mempunyai konsonan afrikat, bahasa tersebut tentu memiliki konsonan frikatif dan konsonan hambat, contoh: Jika bahasa X mempunyai [ts] dan [d] bahasa ini pasti mempunyai [f-v], [t-d], [k-g].

Tahap-tahap pemerolehan fonologi menurut Ingram sesuai dengan tahap perkembangan kognitif Piaget sebagai berikut :

- Persepsi (belum produktif) terdiri dari :

- tahap vokalisasi praucapan (0;4-1;0) ialah tahap sebelum kata-kata 
pertama muncul yang dimulai dengan mendekut, membabel.

- tahap fonologi primitif (1;0-1;6) yaitu mulai muncul ucapan satu kata dalam pemerolehan sintaksis.

- Pengeluaran merupakan tahap proses yang aktif terutama dalam pemerolehan rumus-rumus yang dimulai ketika berusia 1;6. Ada dua peristiwa penting yaitu:

a. Terjadinya pertumbuhan perbendaharaan kata-kata yang tibatiba cepat dan

b. munculnya ucapan-ucapan dua kata. Membabel merupakan suatu bentuk latihan pada seorang bayi dan mempunyai hubungan yang erat dengan seluruh proses pemerolehan fonologi untuk mencerminkan katakata yang diucapkan oleh orang dewasa. Jadi membabel adalah suatu latihan peniruan yang akan bergerak maju sampai vokalisasi spontan tercapai.

Pada tahap pemerolehan fonologi tersebut di atas merupakan tahap perkembangan fonologi yang cepat sekali. Namun pada tahap ini juga anak mulai mengembangkan kemampuan persepsinya dan anak memperoleh satu daftar unsure fonetik yang luas, mulai kehilangan beberapa jenis proses fonologi yang sederhana serta mulai memperoleh satu sistem kontras fonologi.

Menurut teori Ingram bahwa teori Jacobson tidak seluruhnya benar misalnya Ingram menemukan bahwa diantara konsonan yang pertama muncul terdapat juga konsonan dental dan konsonan frikatif. Pemerolehan satu bunyi pada anak berlangsung secara perlahan-lahan. Anak selalu berubah diantara ucapan yang benar dan yang tidak benar secara progresif sampai ucapan orang dewasa tercapai.

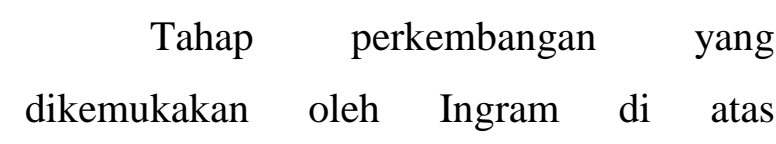
merupakan perkembangan yang dialami oleh anak-anak yang normal atau dalam kondisi sehat. Hal yang menarik adalah tingkat kesehatan dan perkembangan anak tidaklah selalu sama. Beberapa anak mengalami beberapa penyakit yang mengganggun proses perkembangan pemerolehan fonologi mereka. Salah satu kondisi yang akan di angkat dalam penelitian ini adalah anak pasca serangan kejang demam atau yang lebih dikenal dengan istilah step.

\section{KEJANG DEMAM (STEP)}

Kejang demam dapat mengakibatkan gangguan tingkah laku, penurunan kemampuan kognitif dan motorik dan sangat 
mengkhawatirkan orang tua anak. Kejang demam (febris convulsion/stuip/step) yaitu kejang yang timbul pada waktu demam yang tidak di sebabkan oleh proses di dalam kepala (otak: seperti meningitis atau radang selaput otak, ensifilitis atau radang otak) tetapi diluar kepala misalnya karena adanya infeksi di saluran pernapasan, telinga atau infeksi di saluran pencernaan ( Airlangga Universty Press (AUP), 2015).

Penyebab kejang demam hingga kini belum di ketahui dengan pasti. Kejang demam tidak selalu timbul pada suhu yang tinggi, kadang kadang demam tidak terlalu tinggi dapat menyebabkan kejang (Taslim, 2013). Menurut Riyadi, 2013 kondisi yang menyebabkan kejang demam antara lain : infeksi yang mengenai jaringan ektrakranial seperti tonsilitis, ototis media akut, bronkitis. Adapun menurut IDAI, 2013 penyebab terjadinya kejang demam, antara lain : obat-obatan, ketidakseimbangan kimiawi seperti hiperkalemia, hipoglikemia dan asidosis, demam, patologis otak, eklampsia (ibu yang mengalami hipertensi prenatal, toksimea gravidarum) (IDAI, 2013). Angka kejadian kejang demam di Indonesia dalam jumlah persentase yang cukup seimbang dengan negara lain. Disini kejang demam dilaporkan di Indonesia mencapai 2\% sampai 4\% dari tahun 2005 sampai 2006.

Penggolongan kejang demam menurut criteria Nationall Collaborative Perinatal Project adalah kejang demam sederhana dan kejang demam kompleks. Kejang demam sederhana adalah kejang demam yang lama kejangnya kurang dari 15 menit, umum dan tidak berulang pada satu episode demam. Kejang demam kompleks adalah kejang demam yang lebih lama dari 15 menit baik bersifat fokal atau multipel. Kejang demam berulang adalah kejang demam yang timbul pada lebih dari satu episode demam.

Sebagian besar kasus kejang demam sembuh sempurna, sebagian berkembang menjadi epilepsy (2\%-7\%) dengan angka kematian 0,64\%-0,75\%. Kejang demam dapat mengakibatkan gangguan tingkah laku serta penurunan intelegensi dan pencapaian tingkat akademik. Beberapa hasil penelitian tentang penurunan tingkat intelegensi paska bangkitan kejang demam tidak sama, 4\% pasien kejang demam secara bermakna mengalami gangguan tingkah laku dan penurunan tingkat intelegensi. Setelah kejang demam pertama, 33\% anak akan mengalami satu kali rekurensi (kekambuhan), dan 9\% anak mengalami rekurensi 3 kali atau lebih. Beberapa 
penelitian mengatakan rekurensi dari kejang demam akan meningkat jika terdapat faktor risiko seperti kejang demam pertama pada usia kurang dari 12 bulan, terdapat riwayat keluarga dengan kejang demam, dan jika kejang pertama pada suhu $<40$ oC, atau terdapat kejang demam kompleks.

\section{METODE PENELITIAN}

Di dalam penelitian ini, digunakan metode penelitian kualitatif dengan tehnik naturalistik karena memfokuskan perhatian pada situasi kehidupan nyata. Penelitian ini berlangsung kurang lebih 6 bulan terhadap subjek penelitian yaitu nazwa aliya harahap berusia 6 tahun 6 bulan. Nazwa aliya harahap mendapat serangan kejang demam pertama kali pada usia 6 bulan kemudian usia 1 tahun, 1,3, 1,8, 2,6, dan 4,7.

Pada awalnya peneliti yang juga merupakan ibu dari subjek penelitian mengamati Nazwa dan juga membuat perekaman bagaimana Nazwa mengungkapkan kata-kata di dalam pemerolehan fonologinya disamping catatan -catatan ungkapan-ungkapan yang terjadi pada situasi di dalam kesehariannya. Adapun yang dicatat adalah kata-kata yang dapat diujarkan sehari-hari selama Nazwa bermain dengan peneliti, ayahnya, saudaranya, dan juga dengan temannya selama pengambilan data dalam penelitian ini.

Ada dua bagian dalam menganalisis data. Pertama, data dianalisis untuk mengetahui unsur-unsur fonologi (vokal dan konsonan) yang muncul pada pemerolehan fonologi Nazwa. Kedua, setelah menganalisis kemudian di diskripsikan berdasarkan proses pemerolehan fonologi yang dikemukakan Ingram dalam Fletcher (1979 : 135-140). Penelitian ini bertujuan untuk mengetahui informasi tentang pemerolehan fonologi khususnya perkembangan fonologi anak dengan riwayat kejang demam berulang.

Teknik untuk pemeriksaan keabsahan data dengan menggunakan teknik triangulasi. Adapun teknik triangulasi ini terdiri dari empat jenis menurut Moleong (1993:178) yaitu: triangulasi sumber, teori, metode dan penyidik. Dalam penelitian ini hanya menggunakan triangulasi sumber. Instrumen yang digunakan yaitu peneliti sendiri sebab Nazwa adalah anak peneliti. Nazwa merupakan anak kedua dari dua bersaudara dan memiliki satu orang saudara laki-laki yang berusia 7,9 tahun. 


\section{HASIL PENELITIAN DAN PEMBAHASAN}

Berdasarkan hasil pengamatan selama kurang lebih 6 bulan terhadap Nazwa didapatkan bahwa di usia 6 tahun 6 bulan Nazwa telah memperoleh fonem sebagai berikut:

Table 1. Pemerolehan Fonem Nazwa

\begin{tabular}{|c|c|c|c|c|c|c|c|}
\hline Bunyi & \multicolumn{7}{|c|}{ Bunyi vokal Nazwa usia 6 tahun 6 bulan } \\
\hline Vokal & $\begin{array}{l}\quad \text { [a] } \\
\text { - air } \\
\text { - anin ‘angin’ } \\
\text { - adek } \\
\text {-alloh ‘Allah’ } \\
\text { - ambil } \\
\text { - antar } \\
\text { - aban ‘abang } \\
\text { - alam } \\
\text { - arti }\end{array}$ & $\begin{array}{l}\quad \text { [i] } \\
\text { - itu } \\
\text { - sakit } \\
\text { - bisa } \\
\text { - istirahat } \\
\text { - bia(r) } \\
\text { - hijau } \\
\text { - lanit } \\
\text { 'langit' } \\
\text { - ici } \\
\text { 'Rizqy } \\
\text { (nama } \\
\text { saudara } \\
\text { laki-laki } \\
\text { Nazwa) } \\
\text { - didi }\end{array}$ & $\begin{array}{l}\text { [u] } \\
\text { - dula } \\
\text { - 'pulang' } \\
\text { - ujian } \\
\text { - uan 'uang' } \\
\text { - } \quad \text { ku } \\
\text { 'kurang' } \\
\text { - bau } \\
\text { - lupa } \\
\text { - baru } \\
\text { - pusin 'pusi }\end{array}$ & & $\begin{array}{l}\quad \text { [o] } \\
\text {-bole } \\
\text { 'boleh’ } \\
\text {-boneta } \\
\text { ‘boneka’ } \\
\text {-ole-ole } \\
\text { ‘oleh-oleh } \\
\text { - poto 'foto' } \\
\text {-ompon } \\
\text { ‘ompong' }\end{array}$ & $\begin{array}{l}\text { [ð] } \\
\text {-sðmanka } \\
\text { ‘sðmangka’ } \\
\text {-sðpeda } \\
\text {-sðpatu } \\
\text {-sðkaran } \\
\text { ‘sekarang’ } \\
\text {-pðlastik } \\
\text { 'plastik’ } \\
\text {-kðlapa } \\
\text {-kðnak } \\
\text { ‘kðna’ }\end{array}$ & \begin{tabular}{l}
\multicolumn{1}{c}{$[\boldsymbol{\varepsilon}]$} \\
- $\varepsilon$ cnak \\
-berenan \\
'berenang' \\
- $\quad$ ctor \\
‘ekor' \\
-scrak \\
- epaluasi \\
'evaluasi'
\end{tabular} \\
\hline Konsonan & $\begin{array}{l}\text { [p] pelani, put } \\
\text { [b] berat, butu, } \\
\text { [t] tanah, tiap, } \\
\text { [d] daun, desa, } \\
\text { [m] melati, ma } \\
\text { [n] nusa, nanti, } \\
\text { [s] siada, senin } \\
\text { [h] hewan, har } \\
\text { [l] lonsor, lim } \\
\text { [y] yan, yoyo, } \\
\text { [w] wawa, war } \\
\text { [c] cari, ciri, cl }\end{array}$ & $\begin{array}{l}\text {, padi, pita, } \\
\text { panjir, bisa, } \\
\text { Ilan, terima, } \\
\text { dosa, diri, du } \\
\text { as, mintak, n } \\
\text { nilai, nonton } \\
\text { sapu, somb }\end{array}$ & $\begin{array}{l}\text { oos } \\
\text { polu } \\
\text { toto } \\
\text { rian } \\
\text { nungil, mobil } \\
\text {, nenas } \\
\text { n, surat } \\
\text {, hotel } \\
\text { lekas }\end{array}$ & $\begin{array}{l}{ }^{\circ} \mathrm{c} \\
\mathrm{c} \mathrm{n} \\
\mathrm{r} \mathrm{s}\end{array}$ & $\begin{array}{l}\text { elangi, pukul, } \\
\text { erat, butu, banj } \\
\text { nah, tiap, tula } \\
\text { aun, desa, dosa } \\
\text { elati, malas, m } \\
\text { ısa, nanti, nilai } \\
\text { aga, senin, sap } \\
\text { nan, hari, hita } \\
\text { ngsor, lima, lu } \\
\text { awg, yoyo, yuk } \\
\text { i, ciri, cucu, c }\end{array}$ & $\begin{array}{l}\text { agi, pita, pos } \\
\text { r, bisa, bolu’. } \\
\text { g, terima, tok } \\
\text { diri, durian’ } \\
\text { ata, mungil, r } \\
\text { nonton, nena } \\
\text {, sombong, s } \\
\text { n, hutan, hote } \\
\text { a, lapar, leka } \\
\text { ye' } \\
\text { nita' } \\
\text { ana, coklat' }\end{array}$ & $\begin{array}{l}\text { ' } \\
\text { obil”' } \\
\text { rat' } \\
\text {, }\end{array}$ \\
\hline
\end{tabular}




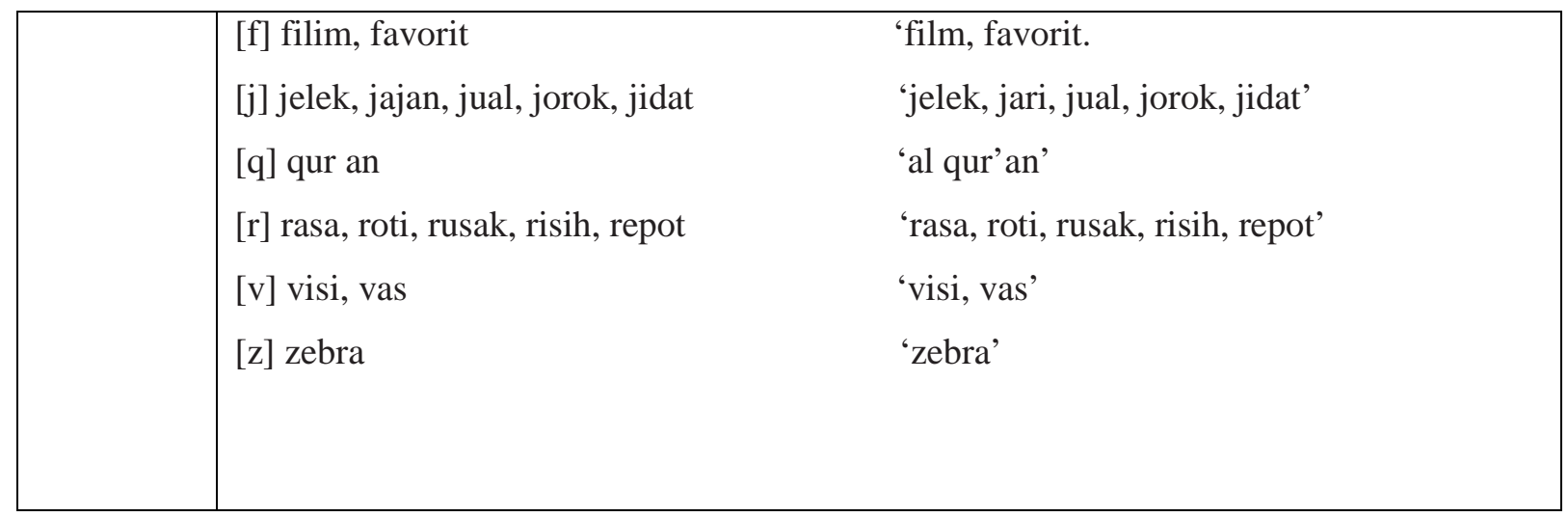

Dari tabel di atas dapat dilihat bahwa Nazwa yang pernah mengalami kejang demam lebih dari 5 kali telah memperoleh keseluruhan suara hidup atau vokal dengan baik. Selama proses pengamatan (observasi) Nazwa akan sering mengalami kegagapan (gagu) ketika akan memulai berkomunikasi sehingga suara vocal di atas menjadi lebih panjang pengucapannya seperti dalam kutipan percakapan berikut ini: "Nazwa sudah makan” Tanya peneliti. “uuuuuudah” jawab Nazwa dengan tergagap dan memanjangkan vocal [u].

Dalam pemerolehan konsonan dapat dilihat dari table di bawah ini:

Table 2. Bunyi Konsonan Nazwa

\begin{tabular}{|c|c|c|c|c|c|c|}
\hline $\begin{array}{l}\text { Titik / } \\
\text { Cara } \\
\text { artikulasi }\end{array}$ & Billabial & $\begin{array}{l}\text { Labio } \\
\text { Dental }\end{array}$ & Alveolar & $\begin{array}{c}\text { Alveolar } \\
\text { Palatal }\end{array}$ & Velar & Glotal \\
\hline Hambat & $\begin{array}{l}\mathrm{b} \\
\mathrm{b}\end{array}$ & & $\begin{array}{l}\mathrm{t} \\
\mathrm{d}\end{array}$ & & - & \\
\hline Afrikat & & & & $\begin{array}{l}j \\
c\end{array}$ & & \\
\hline Frikatif & & $\mathrm{f}$ & $\mathrm{Z}$ & $\mathrm{S}$ & $\mathrm{x}$ & $\bar{h}$ \\
\hline Nasal & $\mathrm{m}$ & & $\mathrm{N}$ & - & & \\
\hline Getar & & & $\mathrm{R}$ & & & \\
\hline Lateral & & & $\mathrm{L}$ & & & \\
\hline Semivokal & $\mathrm{W}$ & & & & $\mathrm{y}$ & \\
\hline
\end{tabular}




\section{DESKRIPSI DATA}

Berdasarkan hasil penelitian yang diperoleh Nazwa usia 6,6 tahun yang pernah mengalami kejang demam lebih dari 5 kali telah memperoleh semua bunyi vokal baik yang berada di awal, tengah maupun akhir kata. Hal yang menarik adalah Nazwa mengalami gagap ketika akan memulai percakapan. Sehingga seringkali vokal Nazwa menjadi lebih panjang dan lama. Dalam kutipan percakapan berikut Nazwa memanjangkan vokal [a] ketika menjawab pertanyaan peneliti pertama kali sebagai berikut:

1. Peneliti: “Nazwa mau kemana?”.

Nazwa: “Aaaaaaawa mau Jajan”.

Dan ketika peneliti melanjutkan kembali bertanya terhadap Nazwa untuk kedua kalinya, maka Nazwa akan menjawabnya dengan baik tanpa terjadi kegagapan.

2. Peneliti: “Sama siapa Nazwa jajan?”.

Nazwa : “Abang Ici”.

Untuk pemerolehan konsonan, Nazwa masih kesulitan untuk memperoleh beberapa konsonan velar diantaranya velar [k,g] jiika bunyi tersebut berada di posisi tengah dan akhir, kemudian dalam pemerolehan suara sengau atau nasal, Nazwa kesulitan dalam memperoleh bunyi [ๆ]. Hal ini terlihat dari pembicaraan sebagai berikut:

1. Peneliti:“Nazwa makan apa?”

Nazwa: "Mmmmmatan roti".

Peneliti:”Roti apa?”.

Nazwa: "Roti Cotat (coklat)”.

2. Peneliti: “Sayangnya Nazwa sama Mama?”.

Nazwa: "Sssssayan”.

Dari kedua contoh percakapan di atas Nazwa masih mengalami kegagapan ketika akan memulai percakapan dan memanjangkan konsonan dari kata pertama yang ingin ia ucapkan. Dalam percakapan yang pertama velar [k] dalam kata [makan] berubah menjadi "matan” atau yang disebut dengan proses substitusi. Kemudian bunyi [k] yang berada dalam kata [cokelat] berubah menjadi [cotat]. Dalam percakapan kedua, konsonan nasal tidak muuncul. Nazwa hanya menglafalkan nasal [n] tidak nasal [n]. 
Untuk konsonan yang lain, Nazwa telah memperolehnya dengan cukup baik. Berdasarkan tahap perkembangan bahasa yang dikemukan Irham untuk anak yang berusia 6 tahun 6 bulan seharusnya telah mampu untuk memperoleh keseluruhan fonem. Dengan kondisi riwayat kejang demam yang pernah dialaminya sehingga Nazwa mengalami kesalahan-kesalahan fonologi khususnya dalam pelafalan konsonan velar dan nasal.

\section{KESIMPULAN}

Berdasarkan hasil penelitian ini dapat disimpulkan bahwa pemerolehan bahasa anak khususnya fonologi dipengaruhi oleh kondisi kesehatan si anak. Anak dengan riwayat kejang demam cenderung mengalami gangguan dalam pemerolehan fonologinya. Hal ini terlilhat dari beberapa percakapan yang dilakukan oleh peneliti dengan Nazwa yang berusia 6,6 tahun.

Nazwa telah memperoleh sebanyak 6 suara vokal baik berada di posisi awal, tengah maupun akhir sebuah kata. Pemerolehan vokal ini juga sedikit terjadi pemanjangan ketika Nazwa memulai percakapan sebab kejang demam yang dialaminya menyebabkan kegagapan atau gangguan ketika berbicara.

Selain fonem vokal, Nazwa juga telah memperoleh konsonan sebanyak 18 bunyi baik konsonan tersebut berada di awal, tengah maupun akhir kata. Terdapat pula beberapa konsonan yang belum dapat dilafalkan Nazwa dengan baik yaitu velar [k,g] dan nasal [n]. Ketika berbicara Nazwa akan melakukan substitusi (penggantian satu segmen ke segmen yang lain).

Melalui penelitian ini diharapkan dapat memperkaya khazanah penelitian khususnya di bidang psikolinguistik khususnya pemerolehan bahasa anak dan dapat memberikan informasi bagi siapa saja yang memiliki pengalaman terserang kejang demam.

\section{DAFTAR PUSTAKA}

Dardjowidjojo, Soenjono.(2000). Echa: Kisah Pemerolehan Bahasa Anak Indonesia. Jakarta : Grasindo

Fletcher,P.\& Garman,M. Language Acquisition.(1985).Cambridge:Cambridge University Press

Fuadi, dkk, (2010), Faktor Resiko Bangkitan Kejang Demam Pada Anak. Fakultas Kedokteran Universitas Diponegoro

Herlina, (2016). Pemerolehan Fonology Pada Anak Usia Dua Tahun Dua Bulan. Universitas Negeri Jakarta. 
Ingram, D. and Stern (1989). Phonological disability in children. 2nd Ed. London: Cole and Whurr Ltd. 